\title{
PERENCANAAN DAN PERANCANGAN MESIN PERAJANG GRUBI SEMI OTOMATIS DENGAN PISAU TIPE INSERT CUTTER SYSTEM SEBAGAI MEDIA PENCACAH UNTUK UMKM DI KABUPATEN KARANGANYAR
}

\author{
${ }^{1}$ Haikal, ${ }^{2}$ Agung Supriyanto, ${ }^{3}$ Nur Cholis, ${ }^{4}$ Yoga Imam Malik, ${ }^{5}$ Aris Setiyawan \\ Program Studi Teknik Mesin, Akademi Teknologi Warga, Surakarta, Indonesia \\ E-mail: basalamahhaikal3@gmail.com
}

\begin{tabular}{|c|c|}
\hline Info Artikel & Abstract \\
\hline $\begin{array}{l}\text { Keywords: } \\
\text { Grubi, design, insert cutter } \\
\text { system, semi automatic, } \\
\text { counter }\end{array}$ & $\begin{array}{l}\text { Tubers are a type of plant that is often processed and consumed } \\
\text { by people in Indonesia. With the development of the era until } \\
\text { now, more and more processed cassava is processed, one of } \\
\text { which is grubi. Karanganyar Regency precisely in tawangmangu } \\
\text { many MSMEs that produce grubi or walangan. Making grubi is } \\
\text { done in a simple way, namely by being chopped manually using } \\
\text { a knife. The purpose of this machine design is to produce a } \\
\text { semi-automatic grubi chopper machine design with spring spur. } \\
\text { The stage in the design of a semi-automatic grubi chopper } \\
\text { machine consists of design ideas, data and material collection, } \\
\text { design design, component calculation, cutting, assembly, testing } \\
\text { and analysis machine. The calculation result of the semi } \\
\text { automatic grubi chopper machine shows that the cutting } \\
\text { capacity is around } 30 \text { kg / hour. The counter mechanism uses an } \\
\text { insert cutter system as a counter media with dimensions of a } \\
45 \times 170 \times 5 \text { mm knife holder plate. Optimal chopping results are } \\
\text { obtained between } 90 \% \text { to } 95 \% \text { at the angle of the blade } 3^{\circ} \text { with } \\
\text { a total of } 83 \text { slicing cutters. }\end{array}$ \\
\hline & Abstrak \\
\hline $\begin{array}{l}\text { Kata kunci: } \\
\text { grubi, insert cutter system, } \\
\text { pencacah, rancang } \\
\text { bangun, semi otomatis } \\
\text { P-ISSN: } 2598-2273 \\
\text { E-ISSN: } 2598-2281 \\
\text { DOI : } \mathbf{1 0 . 3 3 0 6 1}\end{array}$ & $\begin{array}{l}\text { Umbi merupakan jenis tumbuhan yang sering diolah dan } \\
\text { dikonsumsi oleh masyarakat di Indonesia. Dengan perkembangan } \\
\text { jaman hingga saat ini, olahan ketela rambat semakin banyak, } \\
\text { salah satunya adalah grubi. Kabupaten karanganyar tepatnya di } \\
\text { tawangmangu banyak UMKM yang memproduksi grubi atau } \\
\text { walangan. Pembuatan grubi dilakukan dengan cara sederhana, } \\
\text { yaitu dengan dirajang manual menggunakan pisau. Tujuan dari } \\
\text { perancangan mesin ini adalah untuk menghasilkan desain mesin } \\
\text { perajang grubi semi otomatis dengan pendorong pegas. Tahapan } \\
\text { dalam perancangan mesin perajang grubi semi otomatis ini } \\
\text { terdiri dari ide perancangan, pengumpulan data dan bahan, } \\
\text { perancangan desain, perhitungan komponen, pemotongan, } \\
\text { perakitan, pengujian dan analisa mesin. Hasil perhitungan mesin } \\
\text { perajang grubi semi otomatis menunjukkan bahwa kapasitas } \\
\text { perajangan berkisar } 30 \text { kg/jam. Mekanisme pencacah } \\
\text { menggunakan insert cutter system sebagai media pencacah } \\
\text { dengan dimensi pelat dudukan pisau } 45 x 170 \times 5 \text { mm. Hasil } \\
\text { perajangan yang optimal diperoleh antara } 90 \% \text { sampai } 95 \% \text { pada } \\
\text { sudut mata pisau } 3^{\circ} \text { dengan jumlah cutter penyayat sebanyak } \\
83 \text { buah. }\end{array}$ \\
\hline
\end{tabular}

\section{PENDAHULUAN}

Umbi merupakan salah satu organ tumbuhan yang termodifikasi dari organ lain pada tumbuhan yang berfungsi sebagai tempat penyimpan zat tertentu (pada umumnya karbohidrat) (Koswara, 2013). Daun, batang, ataupun akar adalah organ dari umbi yang dapat dimodifikasi. Bentuk modifikasi ini adalah pembesaran ukuran dengan perubahan anatomi yang sangat jelas terlihat.Umbi biasanya 
terbentuk tepat di bawah permukaan tanah atau tertanam didalam tanah bersama akar. Adapun banyak jenis olahan dari umbi-umbian seperti tape yang terbuat dari singkong, grubi yang terbut dari ketela/ubi jalar, perkedel kentang, kentang goreng, getuk dari singkong, klepon dari ubi jalar, dan lain sebagainya (Haikal, Cholis, Malik, \& Setiyawan, 2019).

Grubi adalah makanan yang terbuat dari ubi jalar yang dibentuk seperti bola-bola yang digoreng dan dibumbui dengan gula jawa merah. Bentuk grubi menyerupai bola, akan tetapi terdapat banyak rongga-rongga di dalamnya. Cita rasa grubi yang manis didapatkan dari gula jawa dan memiliki tekstur yang renyah. UMKM yang memproduksi grubi banyak sekali ditemukan di daerah Jawa Tengah, salah satunya terdapat di Desa Karanglo, Kecamatan Tawangmangu, Kabupaten Karanganyar, tepatnya disebelah timur dari kota karanganyar, serta menjadi desa vokasional di Kabupaten Karanganyar (Saptianuri, 2011).

Kelompok petani di Desa Karanglo mempunyai inisiatif dengan membentuk sebuah paguyuban yang tergabung dalam UMKM "Mandiri" yang diketuai oleh Bapak Sugito (58 th), guna mengolah hasil panen polowijo menjadi makanan khas daerah karanglo yaitu grubi dari ketela yang berbentuk makanan ringan. Adapun dalam pembuatan grubi di UMKM tersebut sampai saat ini cara perajanganya masih dilakukan secara sederhana, yaitu dengan cara diparut. Ketela sesudah dikupas dan dicuci kemudian diparut secara manual sehingga hasil yang diperoleh sangat terbatas dari segi waktu dan tenaga juga kurang efektif. Oleh sebab itu, hasil produksi grubi menjadi tidak maksimal dan bergantung dari kekuatan manusia itu sendiri. Apabila pesanan datang dari luar daerah yang cukup banyak maka diperlukan waktu dan tenaga ekstra lembur guna mencukupinya. Namun demikian, tidak semua pesanan dari luar dapat terpenuhi. Hal ini merupakan suatu kerugian didalam bidang usaha, karena hasil tidak sebanding dengan permintaan, apabila mau meningkatkan produksinya tentu menambah tenaga kerja lagi sehingga akan menambah biaya produksi. Dalam upaya meningkatkan produksi grubi, UMKM "Mandiri" memerlukan mesin produksi yang semi otomatis sehingga waktu yang dibutuhkan untuk produksi lebih cepat tanpa harus menambah tenaga kerja. Teknologi tepat guna yang dapat memecahkan permasalahan yang dihadapi oleh UMKM tersebut adalah mesin perajang grubi yang cara kerjanya semi otomatis dalam proses perajangannya.

Mesin perajang singkong umumnya sudah banyak dibuat oleh peneliti sebelumnya, yaitu Lutfi, M dkk (Lutfi, Setiawan, \& Nugroho, 2010) telah membuat mesin perajang grubi dengan Pisau Horizontal. Putro, E.(Putro, 2010) telah membuat mesin perajang singkong dengan mekanisme pedal kaki guna meningkatkan produksi dengan prinsip ergonomic. Mursidi, R. (Mursidi, 2015) telah membuat mesin perajang dengan menggunakan blade sliding dan sistem transfer tenaga semi mekanis dan mekanis. Batubara, H. (Batubara, 2014) menyatakan bahwa penggunaan mesin untuk perajang singkong dapat mengurangi efek keluahan musculoskeletal pada pekerja. Teguh, W. (Teguh, 2012) telah berhasil meningkatkan pendapatan umkm produksi grubi dan tela-tela melalui rekayasa mesin perajang.

Pembuatan mesin perajang singkong sudah banyak dilakukan peneliti sebelumnya. Namun demikian, improvisasi mesin ini masih menjadi topik berkembang hingga sampai saat ini. Hal ini dikarenakan kebutuhan UMKM yang berbeda satu sama lain terkait jenis produk yang dihasilkan. Tujuan dari pengabdian ini adalah merencana sekaligus merancang sebuah mesin perajang grubi semi otomatis dengan pisau tipe insert cutter system sebagai media pencacah untuk UMKM di kabupaten karanganyar. Analisis jumlah dan sudut pemasangan cutter terhadap kualitas rajangan juga dilakukan dalam artikel ini untuk mendapatkan hasil rajangan yang optimum.

\section{RUMUSAN MASALAH}

Mesin perajang grubi semi otomatis hingga saat ini masih dilakukan pengembangan oleh para peneliti dan pembuat alat untuk menghasilkan produksi yang efektif dan efisien. Oleh karena itu, artikel ini berhasil membuat sebuah mesin perajang semi otomatis menggunakan mekanisme pencacah dengan pisau tipe insert cutter system. Pisau ini menggunakan baut yang dibelah sebagai tempat cutter 
sebagai media pencacah dan pisau pelat berdimensi $45 \times 170 \times 5 \mathrm{~mm}$. Pisau mesin perajang grubi menggunakan piringan dengan diameter $50 \mathrm{~cm}$ dan terdapat lubang-lubang tempat baut pisau pencacah dan mata pisau potong. Mata pisau potong yang digunakan menggunakan bahan stainless steel sehingga aman untuk makanan.

\section{METODE PENELITIAN}

Pembuatan alat ini dilakukan di Laboratorium Perkakas Akademi Teknologi Warga Surakarta dan Rumah Nur Cholis yang beralamatkan di Garesan Rt 01/Rw 01, Trayu, Banyudono, Boyolali. Alat dan bahan penelitian adalah; program Autodesk Inventor 2016, satu set kunci pas, satu set kunci ring, mesin bubut, mesin las listrik, mesin gerinda, mesin bor, palu, las, meteran, gergaji potong, gunting pelat, timbangan, mur, baut, motor listrik, besi pelat, pulley, $V$-belt, besi siku, besi poros, pillow block, pisau cutter dan ubi kayu. Poros berbahan ST 40 dengan diameter 1 inch $(25,4 \mathrm{~mm})$.

Pada identifikasi karakteristik dilakukan pengukuran parameter yang meliputi; kecepatan putaran puli, waktu perajangan, dan kualitas potongan yang dibagi menjadi 3 katagori. Tiga sudut dan banyaknya baut digunakan untuk metode penelitian ini yaitu sudut $2^{\circ}, 3^{\circ}$, dan $4^{\circ}$, serta jumlah baut penyayat 74 buah dan 83 buah.

\section{PEMBAHASAN}

\section{- Deskripsi Perancangan}

Mesin perajang yang dirancang dan dikonstruksikan dalam penelitian ini mempunyai beberapa bagian utama yang mendukung operasional kerjanya, antara lain motor penggerak, sistem rangka (frame), sistem transmisi, dan pisau pemotong. Hasil rancangan secara lengkap ditampilkan pada gambar 1.

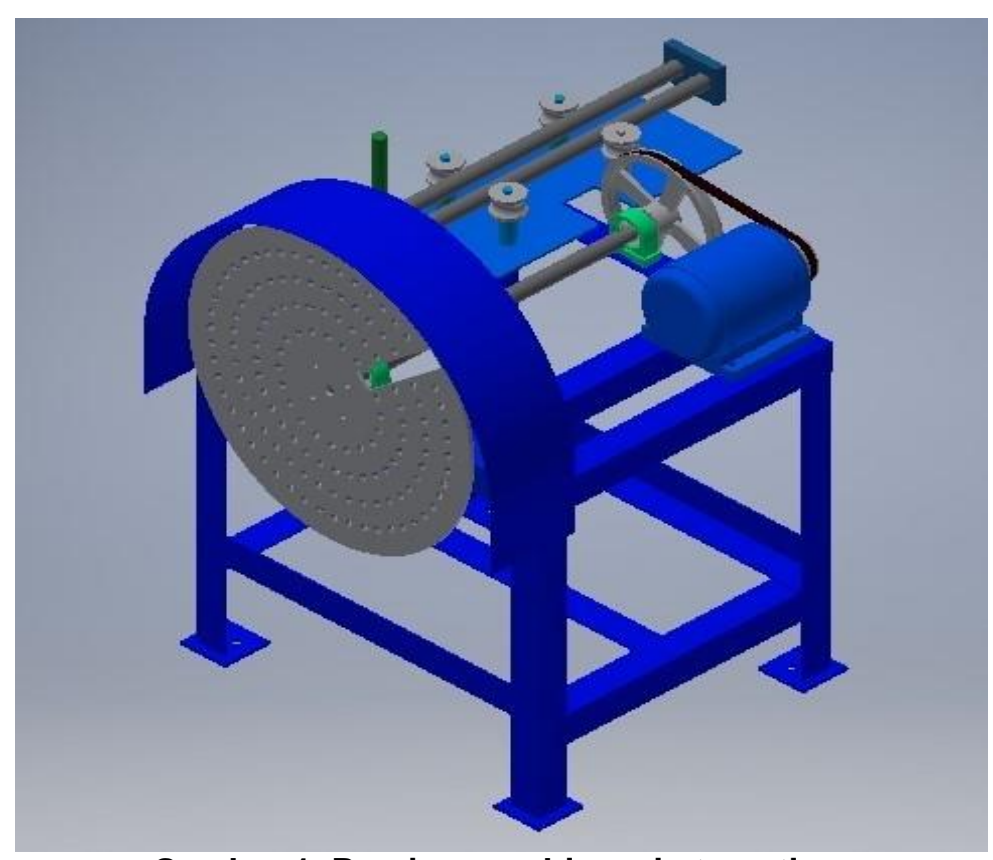

Gambar 1. Perajang grubi semi otomatis

\section{- Motor Penggerak}

Rancangan perajang ini menggunakan motor listrik satu fasa dengan merek MODERN tipe JY09A-4 sebagai tenaga penggerak. Motor memiliki daya sebesar 0.25 HP dengan putaran motor 1400 rpm. Dalam uji coba, motor penggerak mampu berfungsi dengan baik dan tidak ada kendala fungsional. 


\section{- Kerangka}

Kerangka berfungsi untuk menopang seluruh komponen alat perajang. Kerangka ini terbuat dari besi siku $5 \times 5 \mathrm{~cm}$ dengan ketebalan $3 \mathrm{~mm}$ seperti ditunjukkan pada gambar 2. Pemilihan besi siku dengan ukuran tersebut karena alasan teknis, dimana rangka tersebut harus dapat menopang sistem penggerak (motor listrik) dan sistem transmisi (pulley) serta pisau yang berat. Pembuatan kerangka ini tidak mengalami perubahan dan perbaikan bentuk dari perencanaan awal, dan secara fungsional desain kerangka berfungsi baik dan kokoh seperti ditunjukkan pada gambar 3 .

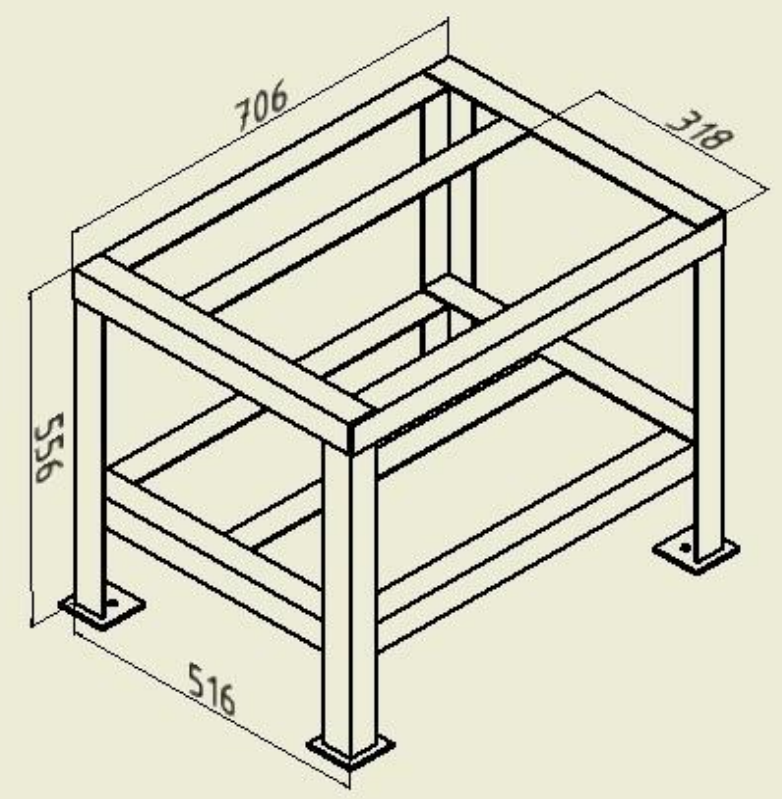

Gambar 2. Rancangan kerangka

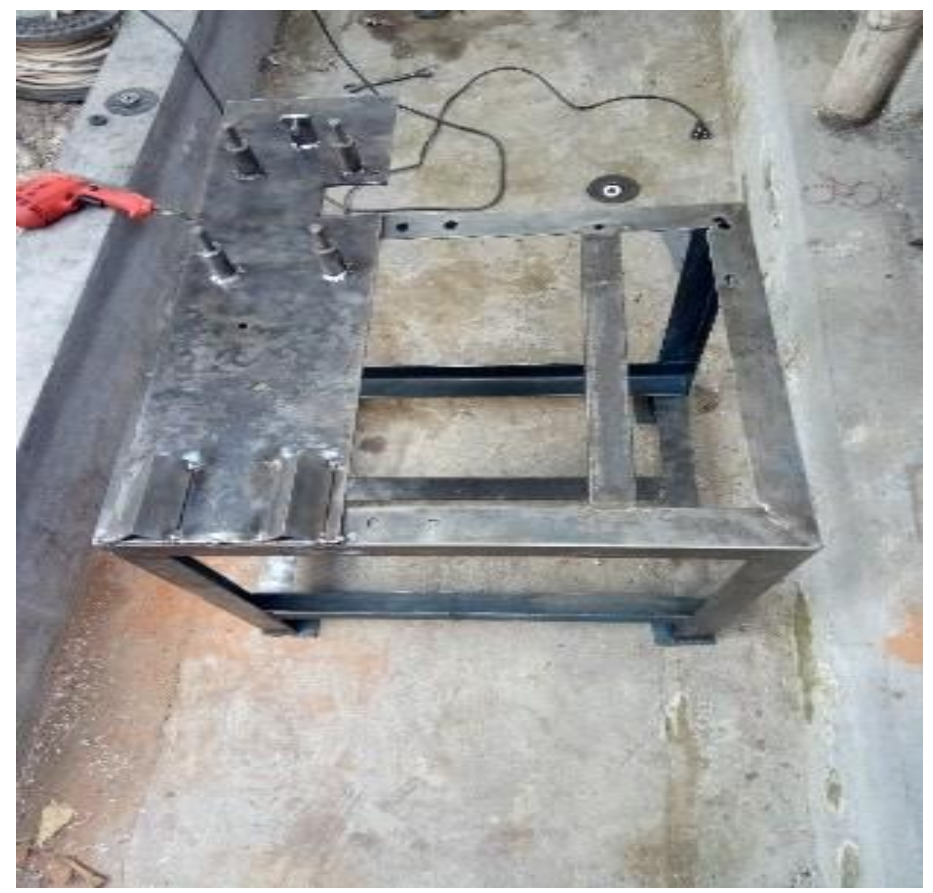

Gambar 3. Kerangka jadi 


\section{- Sistem Transmisi}

Sistem transmisi yang digunakan pada alat perajang ini adalah sistem transmisi sabuk dan puli seperti ditunjukkan pada gambar 4. Puli yang digunakan memiliki diameter $200 \mathrm{~mm}$ dan sabuk $\mathrm{V}$ yang digunakan yaitu sabuk $\mathrm{V}$ dengan seri $\mathrm{A} 36$. Perbandingan diameter puli menghasilkan kecepatan putaran mesin $525 \mathrm{rpm}$.). Hasil pengamatan dapat diketahui bahwa sistem transmisi dapat bekerja dengan baik tanpa ada kendala.

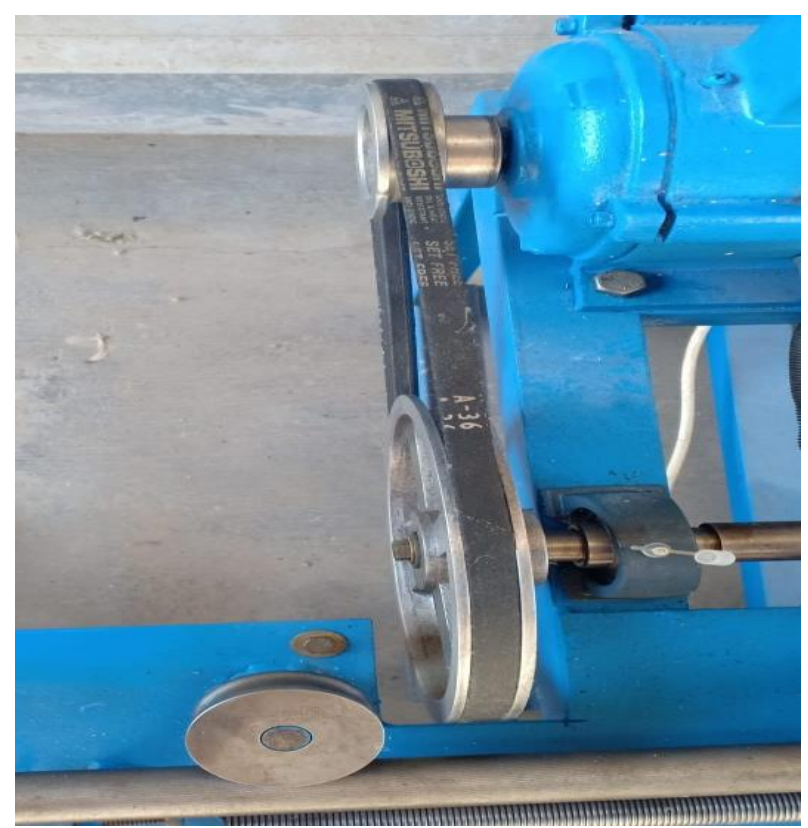

Gambar 4. Sistem transmisi alat perajang

\section{- Pisau Pemotong}

Pisau pemotong berfungsi untuk memotong ubi jalar menjadi bentuk kecil memanjang. Piringan pisau terbuat dari baja ST 37 dengan diameter $500 \mathrm{~mm}$. Piringan tersebut terdapat lubang-lubang yang dibuat untuk tempat cutter penyayat ubi jalar seperti ditunjukkan pada gambar 5 . Pisau pemotong ini terbuat dari bahan baja stainless steel dengan kode AISI 304 yang diasah sehingga salah satu sisinya tajam.

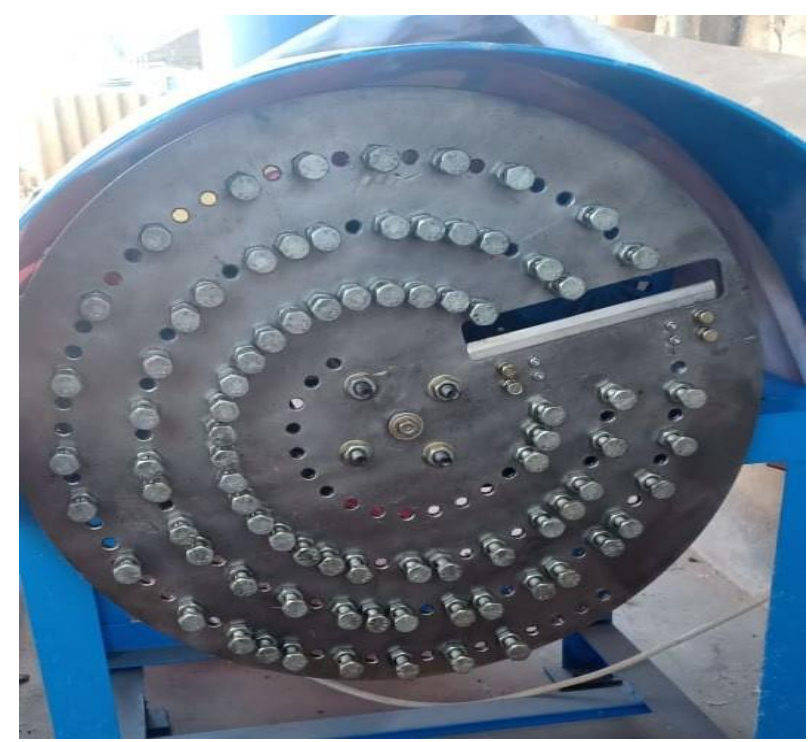

Gambar 5. Pisau perajang ubi jalar 
Berdasarkan pengamatan, pisau perajang dapat bekerja dengan baik. Kendala yang dihadapi adalah pada saat penyetelan pisau dan cutter penyayat karena jumlah cutter yang banyak dan semua harus searah. Penyetelan ini membutuhkan ketelitian lebih besar dan waktu yang lebih lama.

Berdasarkan hasil perhitungan dan rancangan alat seharusnya alat perajang tersebut dapat bekerja baik pada putaran tinggi, tetapi dari pengamatan diketahui bahwa alat mengalami goncangan. Pengurangan goncangan yang terjadi dilakukan dengan cara alat perajang ditanam dilantai dan bahan penyangganya diberi karet untuk meredam getaran. Selain itu, hasil rajangan yang dihasilkan akan maksimal jika sudut pisau dan jumlah cutter penyayat sesuai.

\section{- Karakteristik Mesin Perajang}

Standar bahan umbi yang dipakai sebesar $1 \mathrm{~kg}$. Parameter yang diamati adalah hasil rajangan dengan sudut dan jumlah cutter penyayat yang berbeda. Tabel 1 menunjukkan hasil perajangan pada 3 sudut yang berbeda. Hasil rajangan kemudian dimasukkan ke dalam 3 katagori yaitu A, B, dan C dalam dengan satuan berat $\mathrm{Kg}$. Katagori $\mathrm{A}$ hasil rajangan baik, katagori $\mathrm{B}$ kualitas hasil rajangan sedang, dan katagori $\mathrm{C}$ hasil rajangan yang tidak masuk kriteria diharapkan.

Tabel 1. Hasil Perajangan Berdasarkan Sudut

\begin{tabular}{cccc} 
Sudut & \multicolumn{3}{c}{ Katagori (kg) } \\
\cline { 2 - 4 } Cutter & A & B & C \\
\cline { 2 - 4 } $2^{\circ}$ & 0,52 & 0,31 & 0,17 \\
$3^{\circ}$ & 0,82 & 0,15 & 0,03 \\
$4^{\circ}$ & 0,13 & 0,36 & 0,51 \\
\hline
\end{tabular}

Sudut $4^{\circ}$ menghasilkan goncangan saat merajang terlalu besar diakibatkan karena jarak antara piringan dan ujung mata pisau terlalu lebar sehingga mengakibatkan efek pukulan terhadap ubi jalar. Efek yang terjadi pada ubi jalar mengakibatkan kurang sempurnanya pemotongan dan rusaknya ubu jalar.Rajangan yang dihasilkan cenderung rusak dan pecah.

Perbedaan hasil rajangan yang didapat dengan menggunakan banyaknya cutter penyayat dapat dilihat pada tabel 2. Banyaknya jumlah cutter penyayat yang dipakai berbanding lurus dengan kualitas pemotongan.Pada jumlah cutter penyayat 74 buah rajangan yang dihasilkan lebih banyak yang berada dalam grade $\mathrm{C}$ atau hasil rajangan tidak masuk kriteria yang diharapkan. Sedangkan pada cutter penyayat dengan jumlah 83 rajangan yang dihasilkan lebih banyak masuk di grade $\mathrm{A}$ atau hasil rajangan masuk dalam kriteria yang diharapkan dan yang tidak masuk dalam kriteria sangat minim.

Tabel 2. Hasil Perajangan Berdasarkan Jumlah Cutter Penyayat

\begin{tabular}{cccc} 
Jumlah & \multicolumn{3}{c}{ Katagori (Kg) } \\
\cline { 2 - 4 } Cutter & A & B & C \\
\cline { 2 - 4 } 74 & 0,36 & 0,30 & 0,34 \\
83 & 0,72 & 0,21 & 0,07 \\
\hline
\end{tabular}

Mesin perajang grubi menggunakan sudut mata pisau $3^{\circ}$ dengan hasil yang maksimal yaitu tebal yang dihasilkan berkisar di 1-1,5 mm dan menggunakan jumlah cutter penyayat sebanyak 83 buah dengan hasil sayatan yang masuk ke dalam kriteria lebar yang ditentukan yaitu 1-2 mm seperti 
ditunjukkan pada gambar 6. Kapasitas kerja mesin perajangan grubi ini mampu menghasilkan sebesar $30 \mathrm{~kg} / \mathrm{jam}$. Kapasitas yang dihasilkan bisa berubah karena banyak atau tidaknya ubi jalar yang terajang tergantung pada operator yang memasukkan ubi jalar ke mesin. Kapasitas yang dihasilkan sudah cukup untuk memenuhi kebutuhan UMKM Mandiri dalam memenuhi kebutuhan dipasaran.

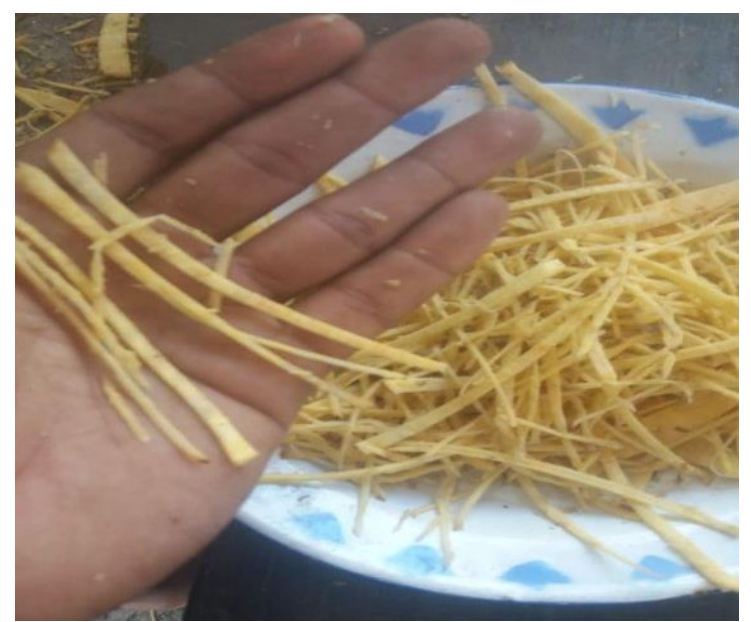

Gambar 6. Hasil rajangan ubi jalar

\section{KESIMPULAN}

Perajang grubi dengan pisau vertikal serta berpenggerak motor listrik berhasil dikonstruksi dan berfungsi dengan baik serta dapat dioperasikan dengan aman. Hasil identifikasi karakteristik mesin perajang otomatis tersebut diperoleh bahwa efisiensi perajangan berkisar antara 90\% sampai 95\% pada sudut mata pisau $3^{\circ}$ dengan jumlah cutter penyayat sebanyak 83 buah.

\section{UCAPAN TERIMA KASIH}

Penulis ingin mengucapkan terima kasih yang tulus atas dukungan keuangan Lembaga Penelitian dan Pengabdian Masyarakat, Akademi Teknologi Warga Surakarta Tahun 2019 dengan judul "Mesin Perajang Grubi Semi Otomatis Guna Meningkatkan Produktifitas Dan Efisiensi Di UMKM Kabupaten Karanganyar".

\section{DAFTAR PUSTAKA}

Batubara, Hafzoh. (2014). Rancang Bangun Mesin Perajang Singkong Untuk Meningkatkan Efisiensi Waktu Perajangan Dan Menurunkan Keluahan Musculoskeletal. Elkha, 6(1).

Haikal, Agung Supriyanto, Cholis, Nur, Malik, Yoga Imam, \& Setiyawan, Aris. (2019). Pengaruh Jumlah Dan Sudut Pemasangan Cutter Terhadap Kualitas Hasil Rajangan Pada Mesin Perajang Grubi Untuk Umkm Di Kabupaten Karanganyar. Senadimas.

Koswara, Sutrisno. (2013). Teknologi Pengolahan Umbi-Umbian. Bogor: Research And Community Service Institution Ipb.

Lutfi, Musthofa, Setiawan, Sigit, \& Nugroho, Wahyunanto A. (2010). Rancang Bangun Perajang Ubi Kayu Pisau Horizontal. Rekayasa Mesin, 1(2), 41-46.

Mursidi, Raden. (2015). Desain Perajang Serbaguna Dengan Tipe Blade Slideng Dan Sistem Transfer Tenaga Semi Mekanis Dan Mekanis. Paper Presented At The Prosiding Seminar Agroindustri Dan Lokakarya Nasional Fkpt-Tpi.

Putro, Eko. (2010). Perbaikan Rancangan Alat Pemotong Singkong Dengan Mekanisme Pedal Kaki Untuk Meningkatkan Produksi Dengan Prinsip Ergonomi. Uns.

Saptianuri, Rinda. (2011). Analisis Usaha Agroindustri Keripik Ketela Ungu Di Kecamatan Tawangmangu Kabupaten Karanganyar.

Teguh, Wiyono. (2012). Peningkatan Pendapatan Umkm Produksi Grubi Dan Tela-Tela Melalui Rekayasa Mesin Perajang Nya Di Tawangmangu, Karanganyar. Majalah Online Politeknosains. 